\title{
Constructivist Views of Cooperation along the Border
}

\author{
Attila Fábián \\ University of West Hungary \\ Faculty of Economics, Institute of International \\ and Regional and Economics, Sopron, Hungary \\ email: afabian@ktk.nyme.hu
}

\begin{abstract}
The present essay makes an attempt to examine the sociocultural field with a constructivist approach, which gives an opportunity to interpret the concept of "border" in a discursive way. This approach emphasises the importance of the role of the ideas and values related to the creation and the development of cross-border regions. The essay places great emphasis on security and cultural communities that are necessary for cross-border cooperation and sustainable regionalism. According to constructivism, security means the communities are in a mutual multi-level connection and people try to avoid conflicts with dialogue, cooperation and socialization. A cultural community along a border is a community created by border societies whose members mutually influence each other. Because of these two aspects, a good neighbourly relation can develop along the border, which may have beneficial effects on the economy of the whole country.
\end{abstract}

\section{Introduction}

The notion of "border" has been defined by many people in many ways. In my opinion, border is a dimension of the cultural landscape. A border may influence the socio-economic picture of neighbouring areas, and has a psychological effect on the attitude of the population along the border; therefore it cannot be disregarded in the course of the examination of the origin and influences of

JEL Classification: R11

Key words and phrases: cross-border cooperation, constructivist approach, security communities, cultural communities 
cultural exchanges. Borders affect the way of framing and accomplishing national policies, since their sheer existence affects the mental map and strategic views of political actors.

There have been clearly distinguishable periods in Hungarian border research until the evolution of the current system of research criteria. The first studies date back to 1988, when the document entitled "Regional and Settlement Development Problems of Regions in Special Situations" was published with the support of the National Midterm Research and Development Plan. This was the first work that paid remarkable attention to the specific characteristics of border regions (Enyedi 1988), (Erdősi 1988), (Kovács, T. 1988). In the same year, János Rechnitzer discussed the connection system of border regions for the first time (Rechnitzer, J. 1988). International cooperative investigation of the Hungarian border regions started in the early 1990s, first on the Austro-Hungarian border (Seger, M., Beluszky, P. 1993). Ten years later, József Nemes-Nagy defined four functions of this specific area: separating module, filter zone, edge and buffer zone and a contact, confrontation and interference zone (Nemes Nagy 1998). This new classification pointed out that growing attention needs to be paid not only to the description of connections and the exploitation of technical cooperation but to the diffuse processes and social, economic and socio-cultural analyses as well.

The results of the following decades research are synthesized by László Kürti (2006). In his opinion, problems of 20th-century territoriality include not only artificially drawn nation state borders but also the territorial expansion of national and ethnic-regional areas or border cultures which penetrate into and through these borders. In his recently published work, Béla Baranyi points out a paradigm shift in cross-border connections. The so-called "mini Euro-regional" cooperation, based on the cooperation between subregions and between towns, gains importance in terms of developing together (Baranyi, 2009).

Naturally, it is not only in Hungary that border research stands in the centre of scientific interest. In international specialised literature, the approaches of scientists of political geography (e.g., Prescott 1987, Agnew 1994, Foucher 2009), cultural anthropology (e.g., Donnan and Wilson 1999) and international relations (e.g., Albert 1998) deserve special attention. Region-building across borders, however, is a process that started only a little longer than a decade ago and was subjected to thorough research, for example in the case of North American borders (Blatter 2001, 2004, Perkmann 2003) and internal European borders (Anderson et al. 2003).

Besides these approaches, I think, the implementation of the socio-cultural 
approach and deep study are necessary in those border areas which are increasingly sensitive and vulnerable in a social sense. After its accession to the EU, Hungary concentrated mainly on infrastructural developments and achieved success in that field, while sustainable social cooperation proved to be less effective. The motivating effect of joint tenders weakened after the grants was used up, while fragmentation remained. The future of the implemented projects depends mainly on the evolution of a common social capital of people living on both sides of the border. This can be regarded as a socialisation and cultural process based on trust and security. Therefore, in my work I attempt to examine the areas along the border in a constructivist approach.

In Section 2 I discuss about the importance of the conflicts fields in crossborder regions, with the examination of security communities which will define the new type of societies. I emphasize that the cooperation is not created only along by rational economic needs, but can also be defined by cultural heritage. In Section 3 I focus on the importance of cultural communities. In Section 4 I examine the question of how the constructivist theory can be integrated in the regional paradigm. In Section 5 I conclude.

\section{Conflict Areas along Borders}

Obviously, during the examination of the origin of cross-border region building the historical background of the given borderland needs to be taken into consideration. Attention needs to be paid to the fact that "border" has a different meaning for those people who got to know the notion during their historical studies but have never lived in a borderland and for those for whom actual local, social movements and local intercultural practices are part of everyday life", says Zoltán Ilyés in his example of the "thousand-year-old border" (Ilyés 2004).

The postmodern or, to put it more precisely, constructivist approach has characterised the mainstream literature of the cross-border cooperation and the way cross-border regions were institutionalised for decades. Constructivism offers suitable tools to reveal historical layers and reinterpret the changes of East European borders. In addition, the constructivist reading of border regions gives the possibility to interpret the semiotics of the border which forms the mutual concepts of "me" and "the other" in an anthropological, discursive way (Newman and Paasi 1998). These mental maps, which are, in fact, the representations of common geopolitical concepts, strengthen outwardly oriented communities in those areas where an artificial border divides an oth- 
erwise homogenous ethnic and language group. These maps can also isolate the "closed communities" from their neighbours. Similar phenomena can be seen in those cases, where persistent diplomatic tensions permanently inhibit local initiatives aimed at cross-border cooperation.

Constructivist approaches emphasise the important role of ideas and (European) values in the creation and development of cross-border regions, and, as a consequence, researchers underline that the aim of region building is to "terminate borders" and they point out subsequent re-territorialisation, which is a characteristic feature of borders within the EU/the Schengen area (Turnock 2002). New concepts for example, "de-territorialisation" (Newman and Paasi 1998) and "de-bordering" (Blatter 2001) have been worked out to describe those multi-dimensional forces which are thought to obscure European borders as a consequence of the enlargement of the EU. The latest research projects that deal with the characteristics and changes of the outer (more specifically, Eastern) borders of the EU attempt to augment the efforts made to work out theories with interdisciplinary and cross-national perspectives. ${ }^{1}$

I share the view of constructivist researchers of international relations according to which borders influence the structure of identity, since border regions are areas where the unique customs and efforts of two or more neighbouring yet different cultures meet. Naturally, constructivism does not aim at exclusiveness; when posing questions as a part of research, one must remain on the ground of reality. Moreover, a key message of the postmodern view which represents the whole era is that there is no exclusive method which leads to the truth. In other words, there is methodological pluralism.

Constructivism is hence is insufficient for interpreting the processes in border regions, since in these areas a pragmatic, realistic way of thinking characterises foreign policies, and cross-border cooperation is examined with adequate circumspection, usually laying stress upon security or the maximisation of benefits, that is, without philosophical conceptions directed simply at building up identity. Through constructivism, social interest and ideational factors ideas, norms and values are upgraded, while the materialistic (production) abilities and the importance of external interests decrease. The constructivist approach, when examining cross-border cooperations, undertakes the examination of se-

\footnotetext{
${ }^{1}$ See e.g. the following trans-national projects: EXLINEA, whose topic is "Borderlines, which Serve for Exclusion, as the Battlefields of Cooperation: The transformation of the outer Borders of Europe Politics, Practices and Perceptions" (http://exlinea.ctc.ee/), EUDimensions, whose topic is: "The Dimension of a wider European neighbourhood: The Establishment of a Political Community with the help of Cross-Border Cooperation and Discussions" (http://www.eudimensions.eu/).
} 
curity communities (Archarya 2001). According to constructivism, if there is no war and there is a reliable social atmosphere in security communities, then it is due not only to the fact that the power is distributed with regards to foreign policy relations, but also and primarily to the fact that the communities have mutual multi-level connections, including building up identities, socialisation, etc. In security communities it is demonstrable that the conflict avoiding attitude is based on dialogue, cooperation, socialisation, norm definition and building up identities, rather than on forces outside these processes (e.g. the distribution of power). The connection between norms and constructivism is interesting inasmuch as norms offer ways and methods not only with regard to the regulation of the behaviour of the state but also in terms of redefining national interest and developing collective identities. Through them, a switch from "regulating" to "redefining" becomes possible. In fact, a typical factor of this is the creation of new habits, which means more than simply assuming a legal obligation to realize something in order to avoid a power which is able to exert force.

It follows that constructivism can heavily rely on the message of those articles by Deutsch which claim that security communities need a certain extent of loyalty to each other, in other words, a share from the common identity (Deutsch 1968). The latter concept includes the emergence of the feeling of "this is us" and those processes which encourage and enhance the experience of belonging to a community. If this feeling arises, security community will become a social habit. To sum up, a new social identity is being created along the borders right now. Consequently, it can be hoped that there evolves a security community which makes an effort to solve problems in foreign and domestic politics in a constructive way. Due to security communities, regional cohesion becomes a long lasting and standing communal value which is based on mutual adaptation and trust. The constructivist approach to regional integration is therefore much more comprehensive than the rational approaches.

In the last decade, numerous case studies were published on cross-border cooperation and Euro-regions. There are interpretations which state that on these borders the revival of personal relations, the establishment of new horizontal networks of the cooperation and the multiplication of the number of participants who take part in cross-border partnerships lead to "re-interpretation" and "crossing" the borders after the cold war, which changes the whole regional geopolitics of wider Europe.

East of Schengen, however, no one believes that borders have lost their importance. Russian researchers prefer interpreting borders as dividing lines which can become places of conflict between the former Soviet neighbours, or 
as lines which serve to "keep" the given country "away" from the EU (Malfliet et al. 2007).

Although in the process of building a cross-border region the dimension of historical remembrance may exist, the documents about the establishment of the Euro-region emphasise instrumental tasks. Hence the identity-creating dimension of the establishment of the Euro-region is subordinated to other, more pragmatic aims such as infrastructural developments whose sustainability is sometimes questionable. This statement conveys that instead of the "founding myths of the Euro-regions", aimed at giving a symbolic meaning to Euro-regions, it is the actual practice of cross-border cooperation (as observed in the Euro-regions) that must be focussed on.

\section{The Importance of Cultural Communities}

Borderlands are not only economic geographical areas but also security communities, scenes of social contacts perceived by individuals where conflicts arise and where different cultures are in contact without losing their traditions and characteristic features. It is also true that this interaction may affect social preferences as well. Borders (wherever they may be) are places where different cultures which do not intend to give up their specificness engage in interaction. Thus "contact zone" can be interpreted as a place where the linguistic, personal and cultural interactions of two adjacent language areas or cultural areas are extremely strong (Keményfi 1994) and cannot be divided into sharply separated units (Barth 1996).

Postmodern anthropologists describe borderlands as temporary zones of uprooting and de-territorialisation which form the identity of people living there (Gupta and Ferguson 1992). The most easily observable interaction is crossing the border, which is a standardised, regulated activity perceptible in the customary patterns of neighbouring societies and states. Due to the numerous rituals connected with border-crossing, anthropologists think that a border is the contact place between symbols and politics which catalyzes the inner paradox of border. In the contact area of "we" and "the other person", it can be observed how cross-border cooperation leads to the changing of values connected with identity in the case of those who cross the border physically and thus "terminate" the border (Donnan and Wilson 1999). Among those people who regularly cross borders, there are commuters, public servants, tourists, students and shopping tourists. They are deliverers of two-way cultural changes, since they deliver certain consumer goods and cognitive patterns parts of 
the cultural landscape of one country to the other. The exhaustive technical literature on cross-border consumption confirms that border crossing changes the value and meaning of goods. Since every border plays an important role in production, trade and consumption, borders themselves become marketable goods: consumer goods which must be wrapped or shown in a way which ensures that they are able to maintain other economic processes and present a positive image of those concepts of the given countrys life which serve as a gate to a country itself (Donnan and Wilson 1999).

The homogenisation of consumer habits and fashion trends, the export of eating habits or tastes in music and the spreading of information are just a few examples for the cultural influence exercised by border crossers. Furthermore, on another level, business culture and the behaviour norms of service activities are transmitted from one country to the neighbouring area via cross-border cooperation.

An example for this phenomenon is Europeanization, by which I mean the dynamic and continuous process of cross-border influences on a material and intellectual level which help European formal rules and common cultural values reach societies outside the EU. A wider interpretation allows for the examination of the institutional/functional dimension of Europeanization the way the acquis communautaire is transposed into the legislation of a non-EU country, and the way it is strengthened in local civic culture through public policy which respects the guidance of Brussels. Secondly, Europeanization includes the less tangible dimensions of external influence of the EU, that is, the transmission and incorporation of (Western) European or EU values into non-European or "less" European cultural outer areas, which finally lead to a pro-Europe attitude to foreign policy.

The cultural landscape of border regions surpasses the political one (Anderson et al. 2003). The outer borders develop their own culture which is mainly formed by regionalisation. This refers to the changing effect of dynamic borders, which in favourable conditions can become a driving force in the evolution of nations and states. Presently, it is seen that most local actors try to make use of the opportunities offered by multilateral cross-border cooperation in a committed way and in a spirit of good neighbourly relations

If these processes are examined through the lens of constructivism, the border can be interpreted as an institution created by society through which people living in border regions mutually influence each other and which affects the self-perception of people living there (in terms of identity, values and interests.) The basis of personal relationships, cross-border cooperation and cultural interactions which characterise borderlands is the feeling that 
good neighbourly relations are necessary and beneficial for the economy of the whole country. These intercultural relations build new feelings of belonging to somewhere where people living along the border make themselves mutually at home. The feeling of "we" starts to develop among the population along the border.

Borders are formed not only by a states security policy, controlling policy and image building. Borders are created in films, novels, memorials and public events (Newman and Paasi 1998), that is, in everyday cultural life which informs researchers dealing with borders about the relative permeability and real (social) cognitive-imaginative situation of borders. The social construction of border can be affected by the new meanings and truths about borders created by historiography, journalism and cinema

With the help of varied and widespread communication tools, discussions and images about the border change the attitudes of the borderlands population towards their neighbours. These discussions and images hybridize the collective ideas of border communities about their border. Thus a different identity of border communities develops which does not necessarily match the habits and mentality of people living in the "centres" (Budapest, Vienna or Brussels.) This differentiation is beneficial inasmuch as they contribute to colourful, culturally many-folded and rich international relations; however, "rural" mentality may cause conflicts as well.

Thus the interactions among the inhabitants of the border area may change peoples social expectations towards central political decisions makers, more specifically, make people more critical towards decision makers. In this sense, the cross-border "diplomatic" behaviour of border regions can filter through from border regions to the central power organisations; and the bottom-up effect of these local economic and social relations have a favourable influence on the nature of interstate relations. In other words, cross-border cooperation and interaction strengthen as Robert Frost says in his poem "Mending Wall" the "good fences" of good neighbourly relations, The population along the border looks after the border collectively and in doing so they force the central governments of the two states to work out more cooperative policies and more integrated frameworks (Frost R. 1914).

The "multiple personality" of the population living along the border implies that a strategy aiming at multiple identities will be developed. This motivates cross-border projects, and involves sub-state participants into the bilateral game with central authorities and external partners. Cross-border cooperation enables local leaders to establish para-diplomatic networks and thus influence central decision makers. Living along the borders enables local authorities to 
build so to say a moral border between themselves and the will of the state by involving European norms and behaviour principles connected to identity.

\section{The Dilemma of Regionalism}

Cross-border cooperation is getting stronger between neighbouring areas which formerly were alienated from each other. This fact unambiguously contravenes Jean Gottmanns statement made three decades ago, namely that "history proves that the political borders drawn on geographical grounds have always been and remained the sources of tensions and conflicts" (Gottmann 1980, cited by Newman and Paasi 1998). Political geographers Newman and Paasi corroborate the relevance of the constructivist approach; they are convinced that postmodern and constructivist schools offer suitable tools for the examination of todays borders. They agree with Gottman on the fact that borders play a central role yet regard them as places of cross-border innovations (interaction and socialisation) rather than as conflict zones.

The sovereignty of the state in a conventional sense is ending because of the multiplication of transnational processes which eliminate borders from the equation of territory, identity and sovereignty. The EU and the local executers of cross-border cooperation also take part in the changing of borders; consequently, there evolve places of interaction where regionalisation meets regionalism, that is intention meets the society characterised by a common identity. However, the borderland is not only the model of a conflict-free contact zone but the generator of growth, a trade bridge and a transit corridor as well, because the border itself was attributed a high priority during the distribution of EU funds in the last decade.

The lesson drawn is that regionalism and regulation are equally necessary for cross-border cooperation, so national and international rules are essential. Cross-border cooperation sustains regionalism instead of ending it. However, one peculiarity must be mentioned. In terms of social action, cross-border interactions eliminate regional borders and change the borders of cultural identity. For the communities living along the border, the proximity of a border is a factor which, in a certain sense, re-territorialises regional identity, moving it away from the centre, and re-orientates local interests toward the outer world.

Regional integration (in our case, cross-border integration) affects the stabilisation of democracy and every field of social life of the neighbouring countries. A basis of future research can be the assumption that the constructivist approach is relevant and more suitable than the rationalist approach. The 
question is whether it is an "absolute requirement" for the explanation of regional integration. In accordance with the feeling of "this is us" in security communities and with the process of interactions among people, the approach which can give a trans-national explanation for regionalism will most probably coordinate ideational factors.

In my opinion, a productive process is a dynamic process of adaptation characterised by socio-cultural feedback rather than a static model of an economic mainstream related to financial capacities and based on the perspectives of rational choices.

From a constructivist approach, the cross-border integration process seems to be a field which can be further analyzed. The innovative cooperation of researchers from Győr, Pécs and Sopron offers an excellent opportunity to research this issue; the cooperation may reveal the conflicts of Croatian-SlovenianAustrian borderlands and may find the possibilities for building up constructive security communities. The theoretical-methodical conclusions of this research could be utilised in the future for analysing the integration processes of other borderlands as well. In my opinion, the shared development of "borderless" social capital could give a new dynamism to the region of the Carpathian Basin. The experience of the series of lectures entitled "The Regions of the Carpathian Basin Introduce Themselves" organised by the Free University of Regional Development of Sopron supports this demand unambiguously.

The performance of this task involves the evaluation of vulnerable points or points which can be criticised and the elimination of deficiencies. Naturally, the are several factors of uncertainty which need to be taken account, such as:

- conventional methods of examining international relations,

- the rational approach to the regional interpretation process,

- the methodology itself, because it is not yet a fully developed holistic method but an approach whose research methodology is still to be elaborated.

\section{Conclusions}

The $21^{\text {st }}$ century has seen the rise of social tension and the lack of constructive co-thinking in communities living along state borders. At the same time, in developed national economies, creativity, innovation and cooperation based on trust are the main drivers of value production and social change. Therefore, a way must be found to project these favourable processes to border regions 
in terms of society, economy and politics and, on this basis, generates societies that extend over national frameworks and have a developing network-like structure.

Consequently, short-term and profit-oriented integration that involves the formal elimination of borders and brings but temporary results will not suffice a multidisciplinary approach is needed that includes fine-tuned socio-cultural drawing closer to each other.

Rationalist simplifications support the centralist integration practice of the state and result in social isolation. Integration remains but a formal tool to protect national interests on the international stage. Albeit political rationalism contributes to the conclusion of certain agreements and/or the introduction of cooperative systems, profit-orientation and a relative lack of trust resulting from competition remain. The sense of community, the feeling of this is us" is moving into the background.

With regard to regional integration, rationalists emphasise the importance of power structure, which, at the same time, is an economic force that affects the short-term competitiveness of border regions. In my study, I point out the opposite: that it is not power-based competition but constructive cooperation that may generate sustainable and long-term social and economic profit.

Thus, economic co-dependence and competitiveness has only short-time effects, while in the long run results in conflict and a defensive, marginalised and passive role. A long-term strategy that prioritises common interests and, above all, common values, may create security communities where conflicts are resolved and an efficient co-development starts. Consequently,

- the integration of border regions is not only of economic nature but of political, social and cultural nature at the same time;

- the communities of border regions where transnational civil society is rooted promote the convergence of values;

- economic and competition-related advantages are easier to be created with the constructive and cooperative utilisation of resources;

- economic success depends on the cooperative ability of the societies in border regions and is based on a strong trust capital or trust communities;

- demand for cooperation is rational and constructive at the same time;

- value production does not exclude maintaining the value of social capital. 
In my opinion, the multifunctional "laboratories" of border regions also entail an opportunity for national and supranational building.

\section{References}

Agnew, J. (1994): 'The Territorial Trap: The Geographic Assumptions of International Relations Theory', Review of International Political Economy, 1 (1), pp. $53-80$

Albert, M. (1998): 'On Boundaries, Territory and Postmodernity: An International Relations Perspective', Geopolitics, 3 (1), pp. 53-68

Acharya, A. (2001): Constructing a Security Community in Southeast Asia. ASEAN and the problem of regional order, Routledge, p. 3

Anderson, J., O'Dowd, L., Wilson, T. M. (2003): New borders for a changing Europe: cross-border cooperation and governance, London, Frank Cass

Baranyi, B. (2009): Paradigmaváltás a határon átnyúló kapcsolatokban, Tér és Társadalom, 2009/2. pp. 25-43

Barth, F. (1996): Régi és új problémák az etnicitás elemzésében. Regio, Kisebbségi Szemle VII. 1, pp. 325

Blatter, J. (2001): 'Debordering the World of States. Towards a Multi-Level System in Europe and a Multi-Polity Stystem in North America Insights from Border Regions', European Journal of International Relations, 7, pp. 175-209

Deutsch, K. W. (1968): The analysis of international relations, Prentice-Hall, p. 214

Donnan, H., Wilson, T. (1999): Borders: Frontiers of Identity, Nation E3 State, Oxford \& New York, Berg;

Enyedi, Gy. (szerk.) (1988): Sajátos helyzetü térségek terület- és településfejlesztési problémái. OKKFT. MTA-RKK. Pécs

Erdősi F. (1988): A határmenti térségek kutatásáról. In: Enyedi György (1988): A sajátos helyzetü térségek terület- és településfejlesztési problémái. MTA-RKK. Pécs Foucher, M. (2009): 'Borders, security and identity', Exploring Geopolitics, (June) Frost, R. (1914): Mending Wall, http://www.poets.org, downloaded: 1 August 2012 Gottmann, J. (1980): Centre and Periphery: Spatial Variation in Politics, Sage Publications, p. 224

Gupta, A., Ferguson, J. (1992): Beyond "Culture": Space, Identity, and the Politics of Difference, Cultural Anthropology, Vol. 7, No. 1, Space, Identity, and the Politics of Difference. (Feb., 1992), pp. 6-23

Ilyés, Z. (2004): A határfogalom változó tartalmai a geográfiától az empirikus 
kultúrakutatásig. In: Kovács Nóra - Osvát Anna - Szarka László (ed.): Tér és terep. Tanulmányok az etnicitás és az identitás kérdésköréből. III. Akadémiai Kiadó, Budapest pp. 9-16

Keményfi, R. (1994): A kulturális határok értelmezésének kérdéséhez. In: Ujváry Zoltán (szerk.) Folklór és Ethnographia 85. In memoriam Sztrinkó István. Debrecen: KLTE, pp. 1322

Kovács, T (1988): Néhány módszertani elképzelés a határ menti térségek szociológiai vizsgálatához. In: Enyedi György (1988): A sajátos helyzetü térségek terület- és településfejlesztési problémái. MTA-RKK. Pécs

Kürti, L. (2006): Határkutatás - a regionális tudományok új ága? Magyar Tudomány, 2006/1 pp. 29-37.

Malfliet, K., Verpoest, L., and Vinokurov, E. (2007): The CIS, the EU, and Russia: Challenges of Integration, London: Palgrave McMillan

Martinez, O. J. (1994): Border People Life and Society in the U.S.-Mexiko Borderlands, TucsonLondon

Nemes Nagy, J. (1998): A tér a társadalomkutatásban. Budapest: Hilscher Rezső Szociálpolitikai Egyesület

Newman, D. and Paasi, A. (1998): 'Fences and neighbours in the postmodern world: boundary narratives in political geography', Progress in Human Geography, 22 (2), pp. $186-207$

Perkmann, M. (2003): 'The Rise of the Euroregion. A Bird's Eye Perspective on European Cross-Border Co-operation', Working Paper, Lancaster, Lancaster University, Department of Sociology

Prescott, J. R.V. (1987): Political Frontiers and Boundaries, London, Allen and Unwin;

Rechnitzer, J (1988): Győr-Sopron megye határmenti kapcsolatai In: Erdősi F, Tóth J (ed.) A sajátos helyzetü térségek terület-és településfejlesztési problémái. Budapest: MTA RKK - TS 2/2. Program Iroda, pp. 80-89.

Seger, M. Beluszky P. (1993): Bruchlinie Eiserner Vorhang. Regionalentwicklung im österreichischem-ungrischen Grenzraum, Böhlau Verlag, Wien-Köln-Graz

Turnock, David (2002): 'Cross-border cooperation: a major element in regional policy in East Central Europe', Scottish Geographical Journal, 118 (1), pp. 19-40. 